\begin{tabular}{ccc}
\hline JOURNAL PHYSICAL \\
HEALTH RECREATION \\
Volume 1 Nomor 1; November 2020 \\
\hline 3
\end{tabular}

\title{
EFFORTS TO IMPROVE THE LEARNING RESULTS OF REJECTED BULLETS THROUGH THE MODIFICATION OF LEARNING MEDIA IN VII GRADE STUDENTS OF SMP NEGERI 3 PERCUT SEI TUAN, 2014/2015 ACADEMIC YEAR
}

\author{
UPAYA MENINGKATKAN HASIL BELAJAR TOLAK PELURU \\ MELALUI MEDIA PEMBELAJARAN YANG DIMODIFIKASI PADA \\ SISWA KELAS VII SMP NEGERI 3 PERCUT SEI TUAN TAHUN AJARAN \\ 2014/2015
}

ANDI AFRIZAL HASIBUAN

SMP NEGERI 2 SIBABANGUN

Jl. Simanosor Kelurahan Sibabangun Kecamatan Sibabangun Kabupaten Tapanuli Tengah

Email: andiafrizalhsb23@gmail.com

\begin{abstract}
ABSTRAK
Berdasarkan hasil penelitian mengenai peningkatan hasil belajar tolak peluru melalui media pembelajaran yang dimodifikasi pada siswa kelas VII SMP Negeri 3 Percut Sei Tuan tahun ajaran 2011/20012. Adapun deskripsi hasil padapre-test yang diperoleh siswa dapat dilihat pada lampiran. Berdasarkan tabel deskripsi hasil pre-test tolak peluru di atas dapat dilihat bahwa kemampuan siswa dalam pembelajaran tolak peluru masih tergolong rendah. Dari 38 orang siswa yang menjadi sampel dalam penelitian ini, ternyata hanya 13 orang siswa $(34,21 \%)$ yang memiliki ketuntasan belajar, sedangkan selebihnya 26 orang siswa $(65,79 \%)$ belum memiliki ketuntasan belajar. Nilai Peningkatan Hasil (PPH) ratarata kelas yang diperoleh hanya mencapai 49,60. Berdasarkan hasil penelitian setelah diberikan berbagai macam bentuk variasi pembelajaran menggunakan alat yang dimodifikasi pada siklus I nilai rata-rata tes hasil belajar 70,92 dengan tingkat ketuntasan belajar 52,63\%. Peningkatan ini terjadi setelah diberikan berbagai macam bentuk variasi pembelajaran dengan media pembelajaran yang dimodifikasi yang dirancang pada siklus II yang beracuan pada refleksi dan pengalaman siklus I. Peningkatan nilai rata-rata hasil belajar siswa yaitu sebesar 12,8 dan peningkatan ketuntasan klasikalnya sebesar $34,21 \%$. Dari hasil observasi, kegiatan pembelajaran yang dilakukan pada siklus I dan siklus II termasuk dalam kategori baik dengan nilai rata-rata 70.92 dan 83.72, terjadi peningkatan sebesar 12.8 siklus per siklus. Dilihat dari hasil ini maka dapat disimpulkan bahwa penggunaan media pembelajaran yang dimodifikasi dapat meningkatkan hasil belajar tolak pelurusiswa kelas VII SMP Negeri 3 Percut Sei Tuan Tahun Ajaran 2011/2012. Dari analisis data yang telah dilakukan dapat disimpulkan denganmenggunakan media pembelajaran yang dimodifkasi dapat meningkatkan hasil belajar siswa, dari tes hasil belajar I yang masih rendah yaitu dengan nilai rata-rata sebesar 70,92 dengan ketuntasan 52\%,63. Untuk selanjutnya perlu dilakukannya perbaikan tindakan pada siklus II. Pada
\end{abstract}


siklus I peneliti menemukan kesulitan yang dialami siswa dalam pembelajaran tolak peluru diantaranya :

Pembelajaran menggunakan media pembelajaran yang dimodifikasi pada siklus I ini belum sesuai yang diharapkan dan hasil belajar siswa juga masih rendah. disebabkan Siswa masih canggung menggunakan media alat yang dimodifikasi dan siswa masih belum serius melakukan gerakan teknik tolak pelurukarena alat modifikasi peluru berupa bola plastik yang diisi oleh pasir dan semen belum pernah mereka gunakan. Peningkatan nilai rata-rata hasil belajar siswa yaitu sebesar 12,8 dan peningkatan ketuntasan klasikalnya sebesar $34,21 \%$. Dari hasil observasi, kegiatan pembelajaran yang dilakukan pada siklus I dan siklus II termasuk dalam kategori baik dengan nilai rata-rata 70,92 dan 83,72, terjadi peningkatan sebesar 12,8siklus per siklus. Dilihat dari hasil ini maka dapat disimpulkan bahwa melalui penerapan pembelajaran dengan menggunakan alat yang dimodifikasi dapat meningkatkan hasil belajar tolak peluru pada kelas VII SMP Negeri 3 Percut Sei TuanTahun Ajaran 2011/2012.

\section{Kata Kunci : Tolak Peluru, Modifikasi, Media}

Based on the results of research on improving learning outcomes through modified learning media for grade VII students of SMP Negeri 3 Percut Sei Tuan in the 2011/20012 academic year. The description of the pre-test results obtained by students can be seen in the attachment. Based on the table of descriptions of the results of the pre-test shot above, it can be seen that the student's ability to learn to shoot a shot is still low. Of the 38 students who were sampled in this study, it turned out that only 13 students $(34.21 \%)$ had complete learning, while the remaining 26 students $(65.79 \%)$ did not have complete learning. The value of the increase in yield (PPH) for the class average obtained only reached 49.60. Based on the research results after being given various forms of learning variations using modified tools in the first cycle the average value of the learning outcomes test was 70.92 with a learning completeness level of $52.63 \%$. This increase occurred after being given various forms of learning variations with modified learning media designed in cycle II based on reflection and experience in cycle I. The increase in the average value of student learning outcomes was 12.8 and the increase in classical completeness was $34.21 \%$. From the observation, the learning activities carried out in cycle I and cycle II were included in the good category with an average value of 70.92 and 83.72, an increase of 12.8 cycles per cycle. Judging from these results, it can be concluded that the use of modified learning media can improve the learning outcomes of class VII students of SMP Negeri 3 Percut Sei Tuan for the 2011/2012 academic year. From the data analysis that has been done, it can be concluded that using modified learning media can improve student learning outcomes, from the I learning outcomes test which is still low, with an average value of 70.92 with completeness $52 \%, 63$. Henceforth, it is necessary to do corrective actions in cycle II. In the first cycle, the researcher found the difficulties experienced by students in learning to shoot bullets, including: Learning using modified learning media in cycle I was not as expected and student learning outcomes were still low. This is because the students are still awkward using the modified media and the students are still not serious about the movement of the bulletrepelling technique because they have never used the modified bullets in the form of plastic balls filled with sand and cement. The increase in the average value of student learning outcomes was 12.8 and the increase in classical completeness was 34.21\%. From the observations, the learning activities carried out in cycle I and cycle II were included in the good category with an average value of 70.92 and 83.72, an increase of 12.8 cycles per cycle. Judging from these results, it can be concluded that through the application of learning using 
modified tools it can improve learning outcomes to shoot bullets in class VII SMP Negeri 3 Percut Sei Tuan 2011/2012 Academic Year.

\section{Keywords: Reject Bullets, Modification, Media}

\section{PENDAHULUAN}

Proses kegiatan belajar mengajar merupakan suatu aktivitas yang bertujuan mengarahkan siswa pada perubahan tingkah laku yang diinginkan. Pengertian ini cukup simpel dan sederhana, akan tetapi bila pengertian ini ditelaah lebih jauh dan mendasar, maka akan terlihat lebih rumit dan begitu kompleksnya sehingga lebih dituntut dalam pengelolaan pembelajaran itu sendiri. Hal tersebut bisa dipahami karena mengarahkan siswa menuju sebuah perubahan dan merupakan suatu pekerjaan yang berat. Pekerjaan ini membutuhkan suatu perencanaan yang mantap, berkesinambungan serta cara penerapan yang baik kepada peserta didik, sehingga peserta didik dapat mengalami perubahan seperti yang diinginkan. .

Berdasarkan hasil pengamatan peneliti yangdilakukan di SMP Negeri 3 Percut Sei Tuan pada jam pelajaran Pendidikan jasmani, peralatan tolak peluru disekolah itu terbatas hanya ada 4buah peluru, 2 untuk putra dan 2 untuk puteri, lapangan disana cukup luas, tetapi yang dapat digunakan untuk kegiatan pembelajaran materi tolak peluru hanya sebagaian kecil. masih banyak ditemukan siswa yang mengalami kesulitan pada teknik dasar penolakan peluru, hal itu terbukti karena banyak siswa yang belum memahami cara memegang peluru dengan benar, cara meletakkan peluru dileher, posisi badan pada saat menolak, cara menolak, hingga sikap badan setelah melakukan tolakan pada gerak akhir kurang tepat. Informasi yang diperoleh dari guru Penjas dari 38 siswa yang ada dikelas VII2 hanya ada 13 siswa yang paham tentang teknik dasar tolak peluru.

Benny Aprial. M dan Dicky Hendrawan dalam jurnal 1st Unimed International Conference on Sport Science (UnICoSS 2019) Physical education materials consist of small ball games, big ball games, athletics, gymnastics, water activities, and health lifestyle. Each student must meet the material competency qualifications with the teaching process delivered by the Physical Education teacher. The material contained in Physical Education is generally the same in each education unit, but the difference is the studies and insights that are adjusted to the level of the education unit.

Dalam pelaksanaan proses belajar tolak peluru biasanya dengan tidak adanya fasilitas yang memadai dapat memberikan kebebasan bagi seorang guru pendidikan jasmani untuk memodifikasi media yang akan digunakan sebagai alat baru khususnya dalam mengajarkan materi praktek dilapangan.

\section{METODE PENELITIAN}

Penelitian ini dilaksanakan di kelas VII SMP Negeri 3 Percut Sei Tuan yang beralamat di Jalan Mesjid No.20 Percut.

Penelitian ini dilaksanakan pada tanggal 27

Februari s/d 7 Maret 2012. Jumlah pertemuan menurut RPP dan Kurikulum pada materi tolak peluru gaya menyamping atau ortodokssebanyak satu kali pertemuan, kalau sudah tercapai KKM yang ditentukan. Tetapi kalau belum tuntas dilaksanakan diluar jam pelajaran.

Penelitian ini adalah penelitian tindakan kelas (Classroom action research) dengan tahapan-tahapan pelaksanaan meliputi; perencanaan, pelaksanaan tindakan, observasi dan, dan refleksi.

Penelitian ini dilaksanakan di SMP Negeri 3 Percut Sei Tuan. Yang menjadi objek dalam penelitian tindakan kelas ini adalah siswa kelas VII2 SMP Negeri 3 Percut Sei Tuan pada semester genap tahun pelajaran 
2011/2012 dengan jumlah siswa 38 orang.

\section{HASIL DAN PEMBAHASAN}

Berdasarkan hasil penelitian mengenai peningkatan hasil belajar tolak peluru melalui media pembelajaran yang dimodifikasi pada siswa kelas VII SMP Negeri 3 Percut Sei Tuan tahun ajaran 2011/20012.

Adapun deskripsi hasil padapre-test yang diperoleh siswa dapat dilihat pada lampiran. Berdasarkan tabel deskripsi hasil pre-test tolak peluru di atas dapat dilihat bahwa kemampuan siswa dalam pembelajaran tolak peluru masih tergolong rendah. Dari 38 orang siswa yang menjadi sampel dalam penelitian ini, ternyata hanya 13 orang siswa $(34,21 \%)$ yang memiliki ketuntasan belajar, sedangkan selebihnya 26 orang siswa $(65,79 \%)$ belum memiliki ketuntasan belajar. Nilai Peningkatan Hasil $(\mathrm{PPH})$ rata-rata kelas yang diperoleh hanya mencapai 49,60.

Berdasarkan hasil penelitian setelah diberikan berbagai macam bentuk variasi pembelajaran menggunakan alat yang dimodifikasi pada siklus I nilai rata-rata tes hasil belajar 70,92 dengan tingkat ketuntasan belajar 52,63\%. Peningkatan ini terjadi setelah diberikan berbagai macam bentuk variasi pembelajaran dengan media pembelajaran yang dimodifikasi yang dirancang pada siklus II yang beracuan pada refleksi dan pengalaman siklus I. Peningkatan nilai rata-rata hasil belajar siswa yaitu sebesar 12,8 dan peningkatan ketuntasan klasikalnya sebesar 34,21\%. Dari hasil observasi, kegiatan pembelajaran yang dilakukan pada siklus I dan siklus II termasuk dalam kategori baik dengan nilai rata-rata 70.92 dan 83.72 , terjadi peningkatan sebesar 12.8 siklus per siklus. Dilihat dari hasil ini maka dapat disimpulkan bahwa penggunaan media pembelajaran yang dimodifikasi dapat meningkatkan hasil belajar tolak pelurusiswa kelas VII SMP Negeri 3 Percut Sei Tuan Tahun Ajaran 2011/2012.

Dari analisis data yang telah dilakukan dapat disimpulkan denganmenggunakan media pembelajaran yang dimodifkasi dapat meningkatkan hasil belajar siswa, dari tes hasil belajar I yang masih rendah yaitu dengan nilai rata-rata sebesar 70,92 dengan ketuntasan 52\%,63. Untuk selanjutnya perlu dilakukannya perbaikan tindakan pada siklus II. Pada siklus I peneliti menemukan kesulitan yang dialami siswa dalam pembelajaran tolak peluru diantaranya :

Pembelajaran menggunakan media pembelajaran yang dimodifikasi pada siklus I ini belum sesuai yang diharapkan dan hasil belajar siswa juga masih rendah. disebabkan Siswa masih canggung menggunakan media alat yang dimodifikasi dan siswa masih belum serius melakukan gerakan teknik tolak pelurukarena alat modifikasi peluru berupa bola plastik yang diisi oleh pasir dan semen belum pernah mereka gunakan. 
Peningkatan nilai rata-rata hasil belajar siswa yaitu sebesar 12,8 dan peningkatan ketuntasan klasikalnya sebesar 34,21\%. Dari hasil observasi, kegiatan pembelajaran yang dilakukan pada siklus I dan siklus II termasuk dalam kategori baik dengan nilai rata-rata 70,92 dan 83,72 , terjadi peningkatan sebesar 12,8siklus per siklus. Dilihat dari hasil ini maka dapat disimpulkan bahwa melalui penerapan pembelajaran dengan menggunakan alat yang dimodifikasi dapat meningkatkan hasil belajar tolak peluru pada kelas VII SMP Negeri 3 Percut Sei TuanTahun Ajaran 2011/2012.

\section{KESIMPULAN}

Berdasarkan hasil belajar siswa pada siklus I setelah tes hasil belajar I dapat dilihat bahwa kemampuan awal siswa dalam melakukan teknik tolak peluru masih rendah. Dari 38 siswa terdapat 20 siswa $(52,63 \%)$ yang telah mencapai ketuntasan belajar, sedangkan 18 siswa $(47,37 \%)$ belum mencapai ketuntasan belajar. Dengan nilai rata-rata hasil belajar siswa 70,92. Sedangkan pada siklus II dapat dilihat kemampuan siswa dalam melakukan tes hasil belajar secara klasikal sudah meningkat. Dari 38 siswa terdapat 33 siswa $(86,84 \%)$ yang telah mencapai ketuntasan belajar, sedangkan 5 siswa $(13,16 \%)$ belum mencapai ketuntasan belajar. Dengan nilai rata-ratahasil belajar siswa adalah 83.72. Berdasarkan hal itu maka dapat ditarik kesimpulan bahwa pembelajaran tolak peluru dengan menggunakan alat yang dimodifikasi dapat meningkatkan hasil belajar tolak peluru pada siswa kelas VII SMP Negeri 3 Percut Sei Tuan Tahun Ajaran 2011/2012.

\section{DAFTAR PUSTAKA}

Adang, Hendrayana Yudha. 2001. Pembelajaran Atletik Pendekatan Permainan Dan
Kompetisi Untuk Siswa SMU/SMK. Jakarta, Depdiknas.

Arikunto, Suharsimi. 2009. Prosedur penelitian (Suatu Pendekatan Praktek), Edisi Revisi IV.

Bahagia Yoyo, dkk. 2000. Atletik, Jakarta : Depdiknsas.

Djamarah. 2000. Strategi Belajar Mengajar. Jakarta, Rineka Cipta

Kristiyanto Agus. 2010. Penelitian Tindakan Kelas (PTK) dalam Pendidikan Jassmani dan Kepelatihan Olahraga. Surakarta .

Mudjiono.2002. Belajar dan Pembelajaran, Jakarta : Rineka Cipta.

M Aprial, Benny Dicky Hendrawan (2019) Modification of Athlete Equipment for Basic Level Physical Education Learning. In: Advances in Health Sciences Research, volume 23 1st Unimed International Conference on Sport Science (UnICoSS 2019)

Ngatiyono. 2004. Pendidikan Jasmani. Solo : PT Tiga Serangkai

Roji. 2006. Pendidikan Jasmani Olahraga dan Kesehatan Untuk SMP Kelas VII, Jakarta : Erlangga.

Slameto. 2010. Belajar dan Faktor-faktor yang Mempengaruhinya, Jakarta : Rineka Cipta.

Soepartono. 2000. Media Pembelajaran. Departemen Pendidikan Nasional Direktorat Jenderal Pendidikan Dasar dan Menengah Bagian Penataran Guru SLTP Setara D-III.

Sudjana. 1990. Metode Statistika, Bandung : Tarsito. 